\title{
The Impact of IGFBP-3/IGFBP-3R System on Obesity-associated Insulin Resistance
}

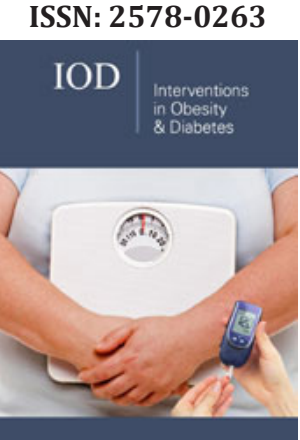

*Corresponding author: Youngman Oh, Department of Pathology, School of Medicine, Virginia Commonwealth University, VA, USA

Submission: 監 December 17, 2019

Published: 眥January 13, 2020

Volume 3 - Issue 3

How to cite this article: Cai Q, Oh Y. The Impact of IGFBP-3/IGFBP-3R System on Obesity-associated Insulin Resistance. Interventions Obes Diabetes 3(3). IOD.000563.2019.

DOI: 10.31031/IOD.2020.03.000563

Copyright@ Youngman Oh. This article is distributed under the terms of the Creative Commons Attribution 4.0 International License, which permits unrestricted use and redistribution provided that the original author and source are credited.

\author{
Qing Cail and Youngman $\mathrm{Oh}^{*}$
}

Department of Pathology, School of Medicine, Virginia Commonwealth University, VA, USA

\begin{abstract}
Obesity is a major risk factor associated with insulin resistance [1-4]. The Visceral fat in obesity secretes various pro-inflammatory and pro-atherogenic adipokines resulting in chronic systemic inflammation and insulin resistance [5,6]. Insulin-like growth factor binding protein-3 (IGFBP-3) inhibits production of proinflammatory adipokines, cytokines as well as inflammatory NF- $\kappa$ B activity through the receptor (IGFBP-3R), which may improve many metabolic disorders including insulin resistance in obesity $[7,8]$. However, the IGFBP-3/IGFBP-3R system appears to be dysregulated in obesity due to neutrophil serine protease (NSP)-induced IGFBP-3 proteolysis in circulation, thereby resulting in loss of its antiinflammatory function [8]. The complete characterization of the underlying mechanism of the NSP/ IGFBP-3/IGFBP-3R cascade in obesity will be benefit for identifying diagnostic and prognostic value of the IGFBP-3/IGFBP-3R axis and therapeutic potential of IGFBP-3R agonists and NSP inhibitors for insulin resistance.
\end{abstract}

Keywords: IGFBP-3; IGFBP-3R; Insulin resistance; Neutrophil serine proteases inhibitors

Abbreviations: T2DM: Diabetes Mellitus; CVD: Cardiovascular Disease; IR: Insulin Resistance; IGF; Insulin-like Growth Factor; IGFBPs: IGF-Binding Proteins; NSP: Neutrophil Serine Proteases; IGFBP-3R: IGFBP-3 Receptor

\section{Obesity-Associated Insulin Resistance}

Nearly two thirds of the adults are overweight or obesity in the United States $[9,10]$. Overweight and obesity is the significant cause of premature death [11-13]. Obesity is a major risk factor for serious comorbidities including hypertension, type 2 diabetes mellitus (T2DM), and other metabolic disorders [14-18]. Most of obesity related comorbidities are associated with insulin resistance (IR) [19-22]. Low grade adipose tissue inflammation contributes to the burden of IR [23,24]. However, the pathophysiology of IR is complex and multifactorial [25]. Thus, elucidation of the mechanisms leading to obesity associated IR is necessary to identify novel targets for the prevention and treatment of many IR driven conditions $[1,26]$.

\section{IGF System}

The insulin-like growth factor (IGF) system is complex, consisting of IGF ligands (IGF-I and IGF-II), the IGF receptors (IGF-IR and IGF-IIR), and six high affinity IGF-binding proteins (IGFBPs) $[7,27]$ Ample evidence indicates that the IGF system plays an important role in cell growth and proliferation $[7,27,28]$ In addition to alteration in other metabolic pathways, perturbations in the IGF-I axis have been implicated in the pathogenesis of IR [28-31]. IGF-I has structural homology with insulin, and also promotes the peripheral uptake of glucose and fatty acids [32]. IGFBP-3, the major binding protein for IGF-I in circulation, forms the $150 \mathrm{kDa}$ ternary complex consisting of IGFBP-3, acid labile subunit (ALS) and IGF-I [33-35]. This ternary complex reduces the passage of IGF-I to the extravascular compartment to extend its half-life [36,37]. In addition to its role as a carrier protein, ample studies point to an IGFIGF receptor independent action of IGFBP-3 in a variety of human diseases including asthma, other inflammatory diseases and cancer [7,27,32,37-42]. Moreover, a novel IGFBP-3 specific receptor (IGFBP-3R) has been identified, and it is expressed in a variety of human tissue and mediates IGFBP-3's intrinsic biological functions including anti-inflammatory functions $[7,39,42]$. 


\section{IGFBP-3/IGFBP-3R Axis and Insulin Resistance}

Current dogma of adipocyte biology indicates that visceral adipocytes not only function as a fuel tank for the storage of lipids and triglycerides but also play more active endocrine role through production of a variety of adipokines and cytokines including leptin, adiponectin, interleukin-6 (IL-6), monocyte chemotactic protein-1 (MCP-1), tumor necrosis factor-alpha (TNF- $\alpha$ ) [43-49]. In obesity, visceral adipocytes enhance the inflammatory milieu by directly secreting pro-inflammatory cytokines and recruiting in situ inflammatory cells including macrophages and lymphocytes [50-53]. IGFBP-3 has been implicated in the pathogenesis of IR $[8,54]$. Interestingly, recent studies demonstrated that IGFBP-3, via activation of IGFBP-3R, inhibits cytokine-induced NF- $\kappa B$ activity, restore insulin signaling, and negates the TNF- $\alpha$-induced inhibition of glucose uptake in human primary adipocytes [8]. However, these anti-inflammatory actions of IGFBP-3 appear to be dysregulated in obesity due to degradation of serum-circulating IGFBP-3 in obesity. Recent study has shown that individuals with obesity demonstrate increases in proteolytic IGFBP-3 fragments and IGFBP-3 protease activity, and corresponding decreases in functional intact IGFBP-3 levels when compared with their normal weight counterparts [8]. Furthermore, IGFBP-3 proteolysis positively correlates with adiposity parameters such as waist circumference, body mass index (BMI), fasting insulin, and insulin resistance index (HOMAIR) in overweight and obese individual [8].

Obesity is associated with activation of neutrophils and the innate immune system [55,56]. Activated neutrophils secret proteinase 3 (PR3) involving in bacterial defense and regulating non-infectious inflammatory processes by modulating the activities of cytokines such as TNF- $\alpha$, IL-1 $\beta$, IL-8, IL-18 and IL-32 [57-61]. Recent studies suggest that neutrophil serine proteases (NSPs) such as PR3, neutrophil elastase (NE) and cathepsin G (CG), contribute to neutrophil-dependent inflammation and progression of chronic inflammatory disease including diabetes, cystic fibrosis and glomerulonephritis [62-66]. Conversely, NSP inhibitors such as $\alpha$-1-antitrypsin (AAT) have been proposed as treatments in patients with chronic inflammatory diseases including diabetes, cystic fibrosis and ischemic heart disease [67-74]. Interestingly, recent studies reported that increased PR3 and IGFBP-3 fragments in the urine of diabetic patients and in the serum of obese individuals [75-77]. In addition, it has shown that PR3 represents an IGFBP-3 specific protease in the serum of obese individuals, whereas AAT completely inhibits PR3-induced IGFBP-3 proteolysis in vitro [75-77]. These findings strongly suggest that IGFBP-3 proteolysis induced by NSPs such as PR3 may result in loss of IGFBP-3R binding ability and subsequent its anti-inflammatory function, and further linking the NSP/IGFBP-3/IGFBP-3R axis in IR and T2DM.

\section{Conclusion}

The rapidly increasing prevalence of obesity, IR and T2DM continues to be a great health problem so that more effective preventive and therapeutic strategies are needed. Thus, a clearer understanding of pathophysiology and the mechanisms involved in obesity-associated IR is necessary to identify novel targets for the prevention and treatment of many IR-driven conditions. The chronic low-grade adipose tissue inflammation contributes substantially to the burden of IR. Recent findings on existence of functional IGFBP-3/IGFBP-3R system in insulin target cells and obesity-induced proteolysis of IGFBP-3 strongly suggest that this anti-inflammatory IGFBP-3/IGFBP-3R signaling plays a critical role during the processes of obesity-associated IR. In this respect, further investigation of the NSP/IGFBP-3/IGFBP-3R axis in obesity will warrant identification of diagnostic or prognostic value of IGFBP-3, IGFBP-3 proteolysis and NSPs, and therapeutic potential of IGFBP-3R agonists (IGFBP-3 and IGFBP-3 mimetics) and NSP inhibitors (AAT and novel small peptide inhibitors) in obesityassociated IR, T2DM and diabetes complications.

\section{References}

1. Kahn BB, Flier JS (2000) Obesity and insulin resistance. J Clin Invest 106(4): 473-481.

2. Bacha F, Saad R, Gungor N, Arslanian SA (2006) Are obesity-related metabolic risk factors modulated by the degree of insulin resistance in adolescents? Diabetes Care 29(7): 1599-1604.

3. Kahn SE, Hull RL, Utzschneider KM (2006) Mechanisms linking obesity to insulin resistance and type 2 diabetes. Nature 444(7121): 840-846.

4. Barazzoni R, Cappellari GG, Ragni M, Nisoli E (2018) Insulin resistance in obesity: An overview of fundamental alterations. Eat Weight Disord 23(2): 149-157.

5. Ouchi N, Parker JL, Lugus JJ, Walsh K (2011) Adipokines in inflammation and metabolic disease. Nat Rev Immunol 11(2): 85-97.

6. Oikonomou EK, Antoniades C (2019) The role of adipose tissue in cardiovascular health and disease. Nat Rev Cardiol 16(2): 83-99.

7. Lee YC, Brahim SJ, Lee DY, Han J, Harada A, et al. (2011) Insulin-like growth factor-binding protein-3 (IGFBP-3) blocks the effects of asthma by negatively regulating NF-kappaB signaling through IGFBP-3R-mediated activation of caspases. J Biol Chem 286(20): 17898-17909.

8. Mohanraj L, Kim HS, Li W, Cai Q Kim KE, et al. (2013) IGFBP-3 inhibits cytokine-induced insulin resistance and early manifestations of atherosclerosis. PLoS One 8(1): e55084.

9. Flegal KM, Moran DK, Carroll MD, Fryar CD, Ogden CL (2016) Trends in obesity among adults in the United States, 2005 to 2014. JAMA 315(21): 2284-2291.

10. Ogden CL, Carroll MD, Lawman HG, Fryar CD, Moran DK, et al. (2016) Trends in obesity prevalence among children and adolescents in the United States, 1988-1994 through 2013-2014. JAMA 315(21): 22922299.

11. Franks PW, Hanson RL, Knowler WC, Sievers ML, Bennett PH, et al. (2010) Childhood obesity, other cardiovascular risk factors, and premature death. N Engl J Med 362(6): 485-493.

12. Di Angelantonio E, Bhupathiraju Sh N, Wormser D, Gao P, Kaptoge S, et al. (2016) Body-mass index and all-cause mortality: Individual-participant-data meta-analysis of 239 prospective studies in four continents. Lancet 388(10046): 776-786.

13. Hruby A, Manson JE, Qi L, Malik VS, Rimm EB, et al. (2016) Determinants and consequences of obesity. Am J Public Health 106(9): 1656-1662.

14. Dubuc PU (1976) The development of obesity, hyperinsulinemia, and hyperglycemia in ob/ob mice. Metabolism 25(12): 1567-1574.

15. Grundy SM, Cleeman JI, Daniels SR, Donato KA, Eckel RH, et al. (2005) Diagnosis and management of the metabolic syndrome. An American Heart Association/National Heart, Lung, and Blood Institute Scientific Statement. Circulation 112(17): 2735-2752. 
16. Guilherme A, Virbasius JV, Puri V, Czech MP (2008) Adipocyte dysfunctions linking obesity to insulin resistance and type 2 diabetes. Nat Rev Mol Cell Biol 9(5): 367-377.

17. Lumeng CN, Saltiel AR (2011) Inflammatory links between obesity and metabolic disease. J Clin Invest 121(6): 2111-2117.

18. Censin JC, Peters SAE, Bovijn J, Ferreira T, Pulit SL, et al. (2019) Causal relationships between obesity and the leading causes of death in women and men. PLoS Genet 15(10): e1008405.

19. DeFronzo RA (2004) Pathogenesis of type 2 diabetes mellitus. Med Clin North Am 88(4): 787-835.

20. Pi Sunyer X (2009) The medical risks of obesity. Postgrad Med 121(6): 21-33.

21. Castro AV, Kolka CM, Kim SP, Bergman RN (2014) Obesity, insulin resistance and comorbidities? Mechanisms of association. Arq Bras Endocrinol Metabol 58(6): 600-609.

22. Zheng Y, Ley SH, Hu FB (2018) Global aetiology and epidemiology of type 2 diabetes mellitus and its complications. Nat Rev Endocrinol 14(2): 88-98.

23. Piya MK, McTernan PG, Kumar S (2013) Adipokine inflammation and insulin resistance: The role of glucose, lipids and endotoxin. J Endocrinol 216(1): T1-T15.

24. Burhans MS, Hagman DK, Kuzma JN, Schmidt KA, Kratz M (2018) Contribution of adipose tissue inflammation to the development of type 2 diabetes mellitus. Compr Physiol 9(1): 1-58.

25. Johnson AM, Olefsky JM (2013) The origins and drivers of insulin resistance. Cell 152(4): 673-684.

26. Czech MP (2017) Insulin action and resistance in obesity and type 2 diabetes. Nat Med 23(7): 804-814

27. Brahim SJ, Feldman D, Oh Y (2009) Unraveling insulin-like growth factor binding protein-3 actions in human disease. Endocr Rev 30(5): 417-437

28. Osher E, Macaulay VM (2019) Therapeutic targeting of the IGF axis. Cells $8(8)$.

29. Ezzat VA, Duncan ER, Wheatcroft SB, Kearney MT (2008) The role of IGF-I and its binding proteins in the development of type 2 diabetes and cardiovascular disease. Diabetes Obes Metab 10(3): 198-211.

30. Rajpathak SN, Gunter MJ, Wylie RJ, Ho GY, Kaplan RC, et al. (2009) The role of insulin-like growth factor-I and its binding proteins in glucose homeostasis and type 2 diabetes. Diabetes Metab Res Rev 25(1): 3-12.

31. Lewitt MS, Dent MS, Hall K (2014) The insulin-like growth factor system in obesity, insulin resistance and type 2 diabetes mellitus. J Clin Med 3(4): 1561-1574

32. Le Roith D (1997) Seminars in medicine of the Beth Israel deaconess medical center: Insulin-like growth factors. N Engl J Med 336(9): 633640.

33. Baxter RC, Martin JL (1989) Structure of the Mr 140,000 growth hormone-dependent insulin-like growth factor binding protein complex: Determination by reconstitution and affinity-labeling. Proc Natl Acad Sci USA 86(18): 6898-6902.

34. Leong SR, Baxter RC, Camerato T, Dai J, Wood WI (1992) Structure and functional expression of the acid-labile subunit of the insulin-like growth factor-binding protein complex. Mol Endocrinol 6(6): 870-876.

35. Ertl DA, Gleiss A, Sagmeister S, Haeusler G (2014) Determining the normal range for IGF-I, IGFBP-3, and ALS: New reference data based on current internal standards. Wien Med Wochenschr 164(17-18): 343-352.

36. Allard JB, Duan C (2018) IGF-binding proteins: Why do they exist and why are there so many? Front Endocrinol (Lausanne) 9: 117.

37. Hwa V, Oh Y, Rosenfeld RG (1999) The insulin-like growth factor-binding protein (IGFBP) superfamily. Endocr Rev 20(6): 761-787.
38. Xu H, Barnes GT, Yang Q, Tan G, Yang D, et al. (2003) Chronic inflammation in fat plays a crucial role in the development of obesity-related insulin resistance. J Clin Invest 112(12): 1821-1830.

39. Ingermann AR, Yang YF, Han J, Mikami A, Garza AE, et al. (2010) Identification of a novel cell death receptor mediating IGFBP-3-induced anti-tumor effects in breast and prostate cancer. J Biol Chem 285(39): 30233-30246.

40. Liss ES, Friedrich N, Dorr M, Schminke U, Volzke H, et al. (2011) Serum insulin-like growth factor I and its binding protein 3 in their relation to intima-media thickness: results of the study of health in Pomerania (SHIP). Clin Endocrinol (Oxf) 75(1): 70-75.

41. Kielczewski JL, Hu P, Shaw LC, Li Calzi S, Mames RN, et al. (2011) Novel protective properties of IGFBP-3 result in enhanced pericyte ensheathment, reduced microglial activation, increased microglial apoptosis, and neuronal protection after ischemic retinal injury. Am J Pathol 178(4): 1517-1528.

42. Han J, Jogie Brahim S, Harada A, Oh Y (2011) Insulin-like growth factor-binding protein-3 suppresses tumor growth via activation of caspase-dependent apoptosis and cross-talk with NF-kappaB signaling. Cancer Lett 307(2): 200-210.

43. Robache GS, Morand V, Bruneau JM, Schoot B, Tagat E, et al. (1995) In vitro processing of human tumor necrosis factor-alpha. J Biol Chem 270(40): 23688-23692.

44. Ouchi N, Kihara S, Funahashi T, Nakamura T, Nishida M, et al. (2003) Reciprocal association of $\mathrm{C}$-reactive protein with adiponectin in blood stream and adipose tissue. Circulation 107(5): 671-674.

45. Neels JG, Olefsky JM (2006) Inflamed fat: What starts the fire? J Clin Invest $116(1): 33-35$

46. Olefsky JM, Glass CK (2010) Macrophages, inflammation, and insulin resistance. Annu Rev Physiol 72: 219-246.

47. Choe SS, Huh JY, Hwang IJ, Kim JI, Kim JB (2016) Adipose tissue remodeling: Its role in energy metabolism and metabolic disorders. Front Endocrinol (Lausanne) 7:30.

48. Kusminski CM, Bickel PE, Scherer PE (2016) Targeting adipose tissue in the treatment of obesity-associated diabetes. Nat Rev Drug Discov 15(9): 639-660.

49. Chouchani ET, Kajimura S (2019) Metabolic adaptation and maladaptation in adipose tissue. Nat Metab 1(2): 189-200.

50. Weisberg SP, McCann D, Desai M, Rosenbaum M, Leibel RL, et al. (2003) Obesity is associated with macrophage accumulation in adipose tissue. J Clin Invest 112(12): 1796-1808.

51. Sartipy P, Loskutoff DJ (2003) Monocyte chemoattractant protein 1 in obesity and insulin resistance. Proc Natl Acad Sci U S A 100(12): 72657270

52. Zeyda M, Stulnig TM (2007) Adipose tissue macrophages. Immunol Lett 112(2): 61-67.

53. Arendt LM, McCready J, Keller PJ, Baker DD, Naber SP, et al. (2013) Obesity promotes breast cancer by CCL2-mediated macrophage recruitment and angiogenesis. Cancer Res 73(19): 6080-6093.

54. Hjortebjerg R, Laugesen E, Hoyem P, Oxvig C, Gron BS, et al. (2017) The IGF system in patients with type 2 diabetes: Associations with markers of cardiovascular target organ damage. Eur J Endocrinol 176(5): 521531

55. Nijhuis J, Rensen SS, Slaats Y, van Dielen FM, Buurman WA, et al. (2009) Neutrophil activation in morbid obesity, chronic activation of acute inflammation. Obesity (Silver Spring) 17(11): 2014-2018.

56. McLaughlin T, Ackerman SE, Shen L, Engleman E (2017) Role of innate and adaptive immunity in obesity-associated metabolic disease. J Clin Invest 127(1): 5-13 
57. Coeshott C, Ohnemus C, Pilyavskaya A, Ross S, Wieczorek M, et al. (1999) Converting enzyme-independent release of tumor necrosis factor alpha and IL-1beta from a stimulated human monocytic cell line in the presence of activated neutrophils or purified proteinase 3. Proc Natl Acad Sci U S A 96(11): 6261-6266.

58. Sugawara S, Uehara A, Nochi T, Yamaguchi T, Ueda H, et al. (2001) Neutrophil proteinase 3-mediated induction of bioactive IL-18 secretion by human oral epithelial cells. J Immunol 167(11): 6568-6575.

59. Novick D, Rubinstein M, Azam T, Rabinkov A, Dinarello CA, et al. (2006) Proteinase 3 is an IL-32 binding protein. Proc Natl Acad Sci USA 103(9): 3316-3321.

60. Korkmaz B, Horwitz MS, Jenne DE, Gauthier F (2010) Neutrophil elastase, proteinase 3 , and cathepsin $\mathrm{G}$ as therapeutic targets in human diseases. Pharmacol Rev 62(4): 726-759.

61. Ng LL, Khan SQ Narayan H, Quinn P, Squire IB, et al. (2011) Proteinase 3 and prognosis of patients with acute myocardial infarction. Clin Sci (Lond) 120(6): 231-238.

62. Kakimoto K, Matsukawa A, Yoshinaga M, Nakamura H (1995) Suppressive effect of a neutrophil elastase inhibitor on the development of collagen-induced arthritis. Cell Immunol 165(1): 26-32.

63. Carden DL, Korthuis RJ (1996) Protease inhibition attenuates microvascular dysfunction in postischemic skeletal muscle. Am J Physiol 271(5): 1947-1952

64. Piwowar A, Kordecka MK, Warwas M (2000) Concentration of leukocyte elastase in plasma and polymorphonuclear neutrophil extracts in type 2 diabetes. Clin Chem Lab Med 38(12): 1257-1261.

65. Zou F, Schafer N, Palesch D, Brucken R, Beck A, et al. (2011) Regulation of cathepsin $\mathrm{G}$ reduces the activation of proinsulin-reactive $\mathrm{T}$ cells from type 1 diabetes patients. PLoS One 6(8): e22815.

66. Lewis EC (2012) Expanding the clinical indications for alpha(1)-antitrypsin therapy. Mol Med 18: 957-970.

67. Martin SL, Downey D, Bilton D, Keogan MT, Edgar J, et al. (2006) Safety and efficacy of recombinant alpha(1)-antitrypsin therapy in cystic fibrosis. Pediatr Pulmonol 41(2): 177-183.

68. Toldo S, Seropian IM, Mezzaroma E, Van Tassell BW, Salloum FN, et al. (2011) Alpha-1 antitrypsin inhibits caspase-1 and protects from acute myocardial ischemia-reperfusion injury. J Mol Cell Cardiol 51(2): 244 251.

69. Talukdar S, Oh DY, Bandyopadhyay G, Li D, Xu J, et al. (2012) Neutrophils mediate insulin resistance in mice fed a high-fat diet through secreted elastase. Nat Med 18(9): 1407-1412.

70. Hashemi M, Naderi M, Rashidi H, Ghavami S (2007) Impaired activity of serum alpha-1-antitrypsin in diabetes mellitus. Diabetes Res Clin Pract 75(2): 246-248.

71. Reeves EP, Dunlea DM, McQuillan K, O’Dwyer CA, Carroll TP, et al. (2019) Circulating truncated alpha-1 antitrypsin glycoprotein in patient plasma retains anti-inflammatory capacity. J Immunol 202(8): 2240-2253.

72. Fahndrich S, Biertz F, Karch A, Kleibrink B, Koch A, et al. (2017) Cardiovascular risk in patients with alpha-1-antitrypsin deficiency. Respir Res 18(1): 171.

73. McCarthy C, Reeves EP, McElvaney NG (2016) The role of neutrophils in alpha-1 antitrypsin deficiency. Ann Am Thorac Soc 13(4): S297-S304

74. McElvaney NG (2016) Alpha-1 antitrypsin therapy in cystic fibrosis and the lung disease associated with alpha-1 antitrypsin deficiency. Ann Am Thorac Soc 13(2): S191-S196.

75. Oh Y, Cai Q Robins JLW (2014) The NSP-IGFBP-3/IGFBP-3R axis is a new therapeutic target for obesity-induced insulin resistance and T2DM. Endocrine Reviews 35(3).

76. Robins J, Cai Q, Oh Y (2013) Impact of proteinase 3 and insulin growth factor BP-3 proteolysis in obesity-induced cardiometabolic risk. Circulation $128(22)$.

77. Robins J, Cai Q Oh Y (2014) The impact of neutrophil proteinase 3 on IGFBP-3 proteolysis in obesity. Internal Medicine: open Access. 